\title{
「保険法10年の経験と今後の課題」： はじめに
}

令和元年度大会シンポジウム

\section{司会 竹 演}

「保険法10年の経験と今後の課題」をテーマとする本シンポジウムは, 2008年 5 月に成立し，2010年 4 月から施行された保険法のこの10年の間に, 実務および学説において得られた経験と課題を提示し, 保険法のより良い解 釈・適用に資することを目的としている。保険法の施行に合わせて，保険約 款の改訂が行われ, 判例も旧法適用ではなく, 保険法が適用される場面が増 えて来た。これらすべてについて短時間で, 網羅的に課題を取り上げること はできないことから，報告者各自がとくに関心を持っているテーマを選んで 報告して頂くこととした。実務家の視点と研究者の視点は, 重なるものばか りではなく，むしろ異なることがあり，関心を高めた課題も相当に異なるが， それによって検討すべき課題の広がりと深まりが期待できることから，その 部分の調整は行っていない。その面では, ややまとまりが不足するのではな いかと思われる点もあろうが, 制約条件の下でできるだけ課題を数多く提示 できるのではないかと考えて, 敢えて制限をしていないことについて, ご容 赦願いたい。

本シンポジウムでは，損害保険と生命保険のそれぞれの実務家の方から高 い関心がある問題を取り上げ，その後で，研究者側が課題としているテーマを 報告し，最後に，経済的観点からの報告を頂くという順で進めることとした。

保険法の章立ての順に, 損害保険実務から (1)東京海上日動火災保険(株)の

*令和元年10月26日の日本保険学会大会 (関西大学) 報告による。

/ 令和 2 年 3 月 20 日原稿受領。 
「保険法10年の経験と今後の課題」：はじめに

森岡圭氏が「損害保険実務からみて保険法10年—『保険給付の履行期』と 『人身傷害の請求権代位』について一」, 研究者側は(2)北海道大学の山本哲生 氏が「直接請求権に関する問題と傷害保険における外来性」を報告し，次に， 生命保険実務から 3日本生命保険(相)の遠山優治氏が「保険法制定後の監督 規制の動向と私法上の課題一生命保険実務の立場から一」, 研究者側は(4)専 修大学の遠山聡氏が「保険金受取人に関する規定の理論的課題とその検討」 を報告し, 最後に, 経済分野から(5)キャピタルコンサルティング社の植村信 保氏が「保険市場の変化一過去10年と今後の展望一」を報告して頂いた。

(1)森岡氏は，保険法によって従来の実務が最も影響を受けたと見られる保 険給付の履行期と請求権代位の問題を取り上げ，判例および約款改訂の実情， そして今後の課題を報告している。2 (2) 本氏は, 自動車損害賠償保障法16条 の直接請求権と請求権代位の関係および傷害保険における外来性の問題を, 判例を踏まえて検討している。前者はこれまで必ずしも注目度がとくに高か つたわけではない理論的論点である。(3)遠山優治氏は, 監督規制と保険法の 関係で論点となる不妊治療保険や生命保険会社が行う直接支払いサービス （現物給付）の問題を検討している。(4)遠山聡氏は, 旧法下と比べて保険法 下での遺言による保険金受取人変更の効力問題などのほか, 保険金受取人の 権利の固有権性を相続法との関係でも検討している。最後に，5植村氏は， この間の保険市場の変化・技術革新と保険契約法への影響を論じている。

いずれも現状を反映した報告であり，最高裁判例や監督官庁の規制等を踏 まえつつも，それぞれの悩ましい部分が述べられており，今後もまだ引続き 検討が進められるべき課題が含まれている。これを契機に，さらに学界，実 際界でいっそうの研究が進められることを期待したい。本シンポジウムの記 録がそれに何ほどか貢献することがあれば，幸いである。

当日，本シンポジウムに熱心に参加された方々に感謝を申し上げる次第で ある。 